\title{
Urban Residents' Religious Beliefs and Influencing Factors on Christianity in Wuhan, China
}

\author{
Junqiang Han ${ }^{1}$, Yingying Meng ${ }^{2, *}$, Chengcheng $\mathrm{Xu}^{3}$ and Siqi Qin ${ }^{4}$ \\ 1 School of Public Management, South-Central University for Nationalities, Wuhan 430074, China; \\ junqianghan@scuec.edu.cn \\ 2 Centre for Social Security Studies, Wuhan University, Wuhan 430072, China \\ 3 Beedie School of Business, Simon Fraser University, Burnaby, BC V5A 1S6, Canada; cxa14@sfu.ca \\ 4 Department of Sociology, The Chinese University of Hong Kong, Shatin, NT, Hong Kong; \\ 1155076790@link.cuhk.edu.hk \\ * Correspondence: yingyingmeng@whu.edu.cn
}

Received: 19 September 2017; Accepted: 1 November 2017; Published: 3 November 2017

\begin{abstract}
In this paper, we conducted an empirical analysis of the reasons for belief in Christianity in Wuhan, China. The data in this paper is from Chinese Urban Research Center for Ethnic and Religious Affairs Management, collected in 2015. We focus on the group characteristics of Christians in urban areas, and its influencing factors. It is found that the Christians in Wuhan are typically older, female, and less educated. Other patterns we have found include powerful influence by family members and friends, pragmatic reasons for following Christianity, family parties as a common way of religious assembly, and discretional admission and exit. Logistic regression is employed here to analyze the determinants of Christian belief. Gender, age, marital status, average annual income, education degree, and health conditions have significant effects on believing in Christianity.
\end{abstract}

Keywords: urban residence; religion; Christian; determinants; China

\section{Introduction}

In recent years, the modern Chinese society has witnessed a rise of Christianity (Jay 1997). Since the implementation of economic reform and opening-up in 1979, many religions have been restored to life and flourished, among which Christianity expands by leaps and bounds (Yang 2010a, 2010b). In urban and rural areas, the number of Christian believers have rapidly increased in recent years. Scholars have debated about the population of Christian believers (Yang 2006). Aikman (2003) has maintained that China has 80 million Christian believers. He also predicts that, by the current trend, one third of the population in the whole nation would be Christian in 30 years. According to the Report of Global Christianity from Pew Research Center in 2011 (Hackett et al. 2011), $5 \%$ of Chinese population was Christian in 2010, including 58 million Protestant Christian and 9 million Catholic. From National Committee of Three-Self Patriotic Movement of the Protestant Churches in China (Wang 2014), by 2014, 23 million to 40 million are Christian, making up of 1.7-2.9\% in the whole population. Trends of the past years indicate supernormal growth of Christianity. Yunfeng Lu and Chunni Zhang (Lu and Zhang 2016) applies five methods to the data in Chinese General Social Survey and China Family Panel Studies and reveals that 1.93-2.2\% percent of China's total adult population is Christian. Adult Christian population is between 14 to 16 million, while the total population is 25.68 to 29.36 million. In sum, regardless of the specific number, the fact that the population of Chinese Christian ranks second (after Buddhism) is beyond doubt (Religion and Culture Research Task Group of PKU and Lu 2014).

Why does Christianity flourish in China? Chen Cunfu (Chen and Wu 2005) points out that, since the 1980s, unpredictable natural calamities and man-made misfortunes left rural residents more 
prone to suffer poverty and disabilities. They resort to prayers in the hope to change the current status. Landryderon (Landryderon and Tiedemann 2011) indicates that the historical surge of Rural Christian Church is connected with political, social and cultural factors and family ethics. Nie (2000) and Yao (Yao et al. 2003) both addressed the pluralistic value system formed during economic reform, the fast-changing social reform, and globalization, as well as the universality of Christianity, factors which made Christian the only psychological consolation for socially vulnerable groups. Yang (2010a) and Ruan et al. (2014) point out that as the reform and opening and the urbanization transitions weaken and break old social networks, a new form of social network emerges under the circumstances, giving rise to religions.

Scholars have focused on the group characteristics of Christians in rural areas, and their influencing factors. Concerning group characteristics, Li and Xing (Xing 2007) have summarized the main characteristics of Chinese Christianity in the 1980s: Christians are mainly located in the impoverished area, especially rural areas. In the rural areas, farmers in impoverished villages are more likely to follow Christianity than those in richer regions. Zheng (Zheng et al. 2010) recapitulated the characteristics as: farmers (as relative to urban residents), aged, female, and illiterate. Based on a study in Gansu Longzhongmin village, Lu and Chen (2006) discovered that the reasons of people's belief in Christianity, the proselytizing process, and religious activities have distinctive Chinese characteristics. Based on generational analysis, Li (2015) suggested that the generation born and raised after the reform and opening up, is less culturally nationalistic, and more accepting towards Christianity. Lu and Zhang (2016) found that Christianity has spread out in China, but agglomerated in some parts.

As for the determinants, social factors include religious freedom and the opening-up policy, and personal factors include life experience and psychological need, Christian's doctrines, organizational structure, ritual, and activities all contribute to the faith in religion (Pye 2005). There is another study which found that, in China, people are more likely to believe in religion if their relatives, friends, and families are Christians (Lu and Zhang 2016). Many studies address how disease, hardship, and mental disturbances make people more likely to follow Christianity (Mooney 2004; Ruan and Liu 2011).

To summarize the aforementioned studies, scholars in China and abroad have addressed the group characteristics and the religious activities of Chinese Christians, and a major part of the literature focuses on the rural residents, the elderly and the females among Christians as well as the reasons of Christian belief. A number of other scholars have paid attention to the development of Christianity in urban areas. Fenggang Yang (Yang 2010b) claimed that Protestantism's fast expansion in urban China is not due to recruiting materially and socially deprived, marginalized people. Instead, more and more well educated young urban residents seek to join Christianity. The micro-level factors of individual crisis, individual choices and personal bonds, the meso-level institutional factors of organizational strengths and competitiveness, and the macro-level factor of the increasingly globalized market economy all contribute to such phenomenon. Cao Nanlai (Cao 2013) on the other hand, tried to explain the reason why Christianity could spread rapidly within different social classes in highly commercialized urban areas in China through his study in Wenzhou, Zhejiang. He has revealed that a modernizing state, lax local governance, emerging capitalist consumer economy, and greater spatial mobility among individuals are important factors. Jie Kang (Kang 2015) has investigated the Christian social network development in China through studying the home churches in Linyi, Shandong in both rural and urban areas. He pointed that interaction and communication through informal social network are to some extent more efficient than institutionalized and formally regulated networks, and better at facilitating the expansion of Christianity. Additionally, qualitative description, compared with micro-empirical research, is a more common approach.

In China, the rural and the urban areas are two drastically different "worlds". The rural area is where residents are mainly engaged in agricultural production. The dominant economy of rural areas is natural economy, and the main industry is agricultural industry. Population density is relatively low, and the economic development level is relatively backward. In contrast, urban areas 
are human settlements formed through the congregation residents are engaged in non-agricultural production. Commodity economy is the dominant form of economy, supported by industrial production, manufacturing and other non-agricultural industries. High population density, high level of economic development and well-developed infrastructure characterize the urban area. "The Green Book of 2013 China Small and Medium-sized City" pointed out that, according to China's urban population size and population distribution status, urban scale classification criteria are: urban population below 500,000 for small cities, 500,000 to 100 million for medium-sized cities, 1 million to 3 million for the large city, 3 million to 10 million for the giant city, and more than 10 million for the megacity. Under the previous planned economic system, the urban areas were separated from the rural areas in dimensions, including economics, education, social network, traditional culture, and social welfare (Tsai 2007). Insights into urban residents will make a contribution to the study of Chinese Christianity.

This data in this paper is from the Chinese Urban Research Center for Ethnic and Religious Affairs Management, collected in 2015. In this paper, we examine the reasons for belief in Christianity in Wuhan, China by empirical analysis. We focus on the group characteristics of Christians in urban areas, and its influencing factors.

Wuhan is one of the earliest cities that received Christian influence (Standaert and Tiedemann 2001). As early as the 1830s, Christian branches like Gefei tang, hualong zongtang, rongguang tang, hanyang tang, were set up in Wuhan. Wuhan has 41 churches, among the top cities in China. Due to the long history, Wuhan has a large population of Christians of 80,000, and 113 registered associations (Wang 2014). Moreover, Wuhan is the largest and most populated city in Central China, with 8467 square kilometers, and regular residents of 10.6077 million (People's Republic of China 2015). Taking Wuhan Christians as an example is, therefore, representative of the whole nation to a certain degree. It should be clarified that Christianity includes Catholicism, Orthodox Church, Protestantism and other smaller religious institutions, Catholicism and Protestantism being the two most prominent in China. Our questionnaire has differentiated between them. Protestantism is the focus of our study, and "Christianity" refers to Protestantism in this article if not specified otherwise.

\section{The Survey for Wuhan Urban Residents}

\subsection{Brief Introduction to the Data Collection Process}

The Chinese Urban Research Center for Ethnic and Religious Affairs Management randomly distributed questionnaires to 6000 Wuhan residents in Jiang'an, Jianghan, Qiaokou, Hanyang, Wucang, Hongshan, Qingshan, Donghu High Tech, Xinzhou, Hannan, and Jiangxia districts. The content includes whether the participant is Christian, their age, gender, industry, education, health conditions, and social insurance. A total of 4929 questionnaires are returned, with a return rate of $82.15 \%$. Outliers excluded, we obtained 4092 valid questionnaires, 68.2\%. Following the survey, we organized in-depth interview with some of the Christian respondents. We randomly selected 4 participants from each district to interview, and interviewed 44 in total. The content of the in-depth interview included their self-evaluated social status, family members suffer from disease, social interactions and associations, the relationship with the church and fellow Christians, their understanding of Christianity, their opinions on the house church, the reasons for selecting certain places for religious activities, Christian influence on the life, the relationship between Christianity and traditional Chinese customs. In addition to interviews with religious believers, we also interviewed five leaders in charge of the non-registry church and five leaders in charge of the registered church. The interviews are mainly concerned with the group characteristics of the believers, the fluctuation in number of believers and the reasons, activities organized by the church, and the relationship between their churches and the local government or other religious organizations. It helped us much in understanding their lives, 
opinions and psychological states, and improved our knowledge of the details of the religious activities of urban Chinese Christians.

\subsection{Urban Residents' Faith Profiles}

Among the 4092 questionnaires, 889 demonstrated that they believe in religion. The religion category is listed in Table 1: 14.69\% are Buddhist, ranking in first place, with Christianity and Islam following, comprising $2.86 \%$ and $1.64 \%$. These three religions are the largest in the world, as well as in China.

Table 1. Religious affiliation among urban residents.

\begin{tabular}{cccccccc}
\hline & \multicolumn{9}{c}{ Believer of Religions } & \multicolumn{3}{c}{ No Religion } \\
\cline { 2 - 8 } & Christian & Catholicism & Islam & Buddhist & Taoism & Others \\
\hline Number & 117 & 14 & 67 & 601 & 38 & 52 & 3203 \\
Percentage & 2.86 & 0.34 & 1.64 & 14.69 & 0.93 & 1.27 & 78.27 \\
\hline
\end{tabular}

\subsection{Comparison of Christian, Other Religions, and Non-Religious Urban Residents}

Table 2 analyses the comparison of Christian, Other Religions, and Non-Religious Urban Residents. For gender, Christianity is similar to the other religions. Females comprise the majority of Christians, at $58.12 \%$. For age, only $8.55 \%$ of youth and young adults ( 35 years old and below) follow Christianity, less than the other religions (12.69\%); the aged comprised the greatest portion, $48.72 \%$, much higher than the other religions (38.34\%).

From marital status, most of the Christians are married (69.32\%), followed by divorced and windowed $(21.37 \%)$. The fewest are those who are single, at only $9.4 \%$. From the perspective of ethnicity, the Han ethnicity comprises the majority of the Christian, at $94.02 \%$. The rest $(5.98 \%)$ are of ethnic minorities. This is similar to the other religions.

For political status, similar to the other religions, most Christians have no political faith, with only three participants admitting that they have political faiths. In terms of education, only $37.61 \%$ of Christians attend high school, college, or university, a figure much lower than other religions' followers. A total of $29.91 \%$ Christians finished elementary education and below, worse than other religion's followers. It is worth noting that $12.82 \%$ of Christians finished college or university degrees, as it reflects that even the average Christian is not well educated, those with a high education degree comprise a large portion of urban resident Christians.

For employer enterprise ownership, 53.85\% work in individual- and privately-owned enterprises, and $14.53 \%$ are unemployed. More than two thirds are flexible employees.

For income level, 3.42\% reach an annual income of 100,000 RMB. Only $37.61 \%$ and $12.82 \%$ have an income of 20,001-50,000 or $>50,000 \mathrm{RMB}$, lower than other religions, while $46.15 \%$ of the Christians earn less than 20,000 RMB, whereas in the survey, non-religious urban residents earned an average annual income of 27,051.47 RMB. This illustrates that Christians earn a lower income than the urban residents.

For health conditions, we adopt the method from epidemiology and medical statistics, using chronic disease as a measurement of body condition. Only $26.5 \%$ of the Christians have no chronic diseases, and $46.14 \%$ have more than two types of chronic diseases, a higher figure than the other religion followers. This reflect that a large portion of Christians do not have an ideal body condition. From the social insurance, only $76.92 \%$ and $67.52 \%$ are insured under medical plans and pension plans, less than the other religious followers and non-religious residents. 
Table 2. Comparison of Christian, other religions, and non-religious urban residents.

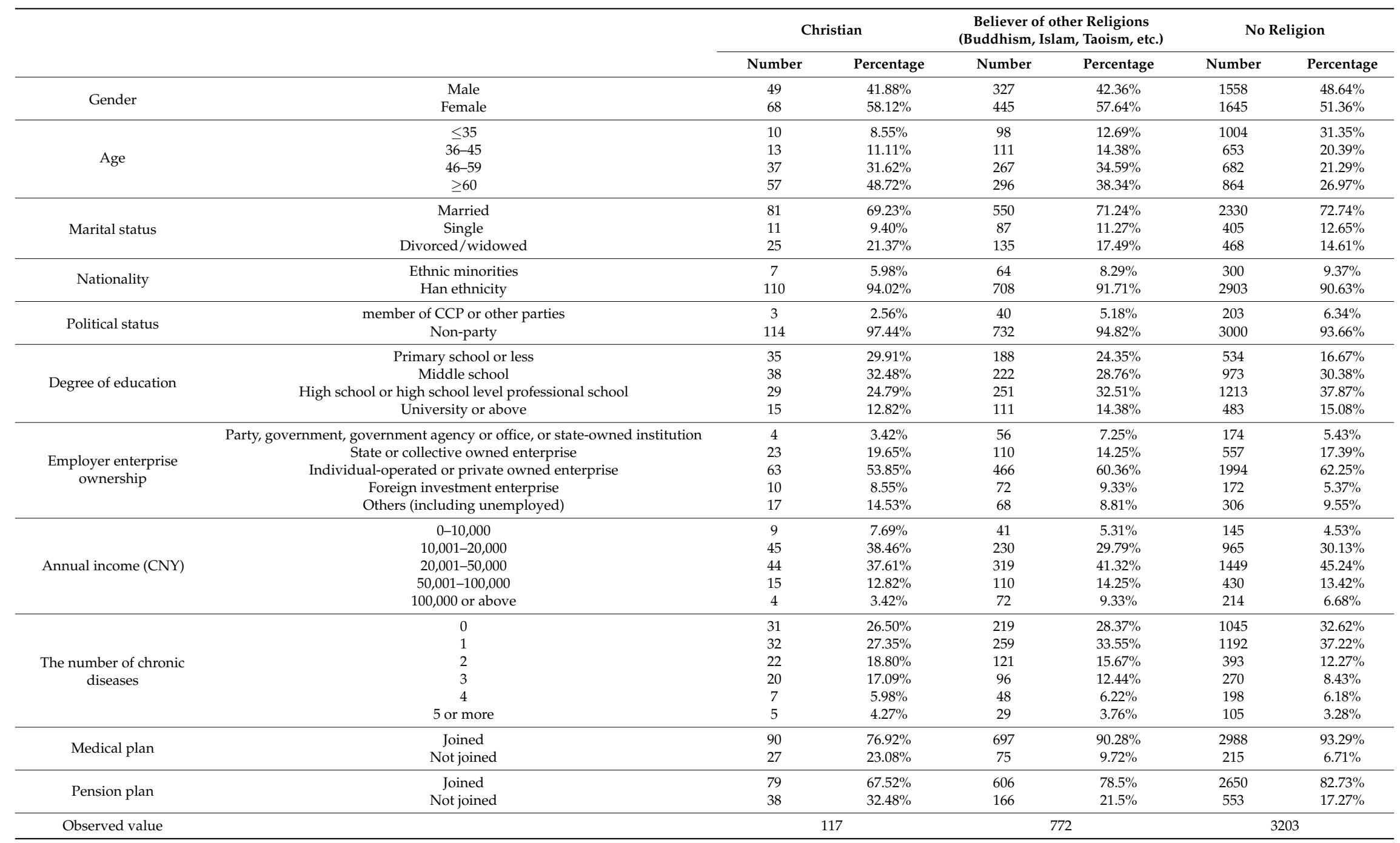




\subsection{The Status of Urban Christians}

\subsubsection{The Age when City Dwellers Started in the Christian Faith}

Figure 1 addresses the age when city dwellers started in the Christian faith. Most Christians, $49.9 \%$, started to follow Christianity after 60 years of age. Next came the middle aged, at $22.5 \%$. Few people started when they were young.

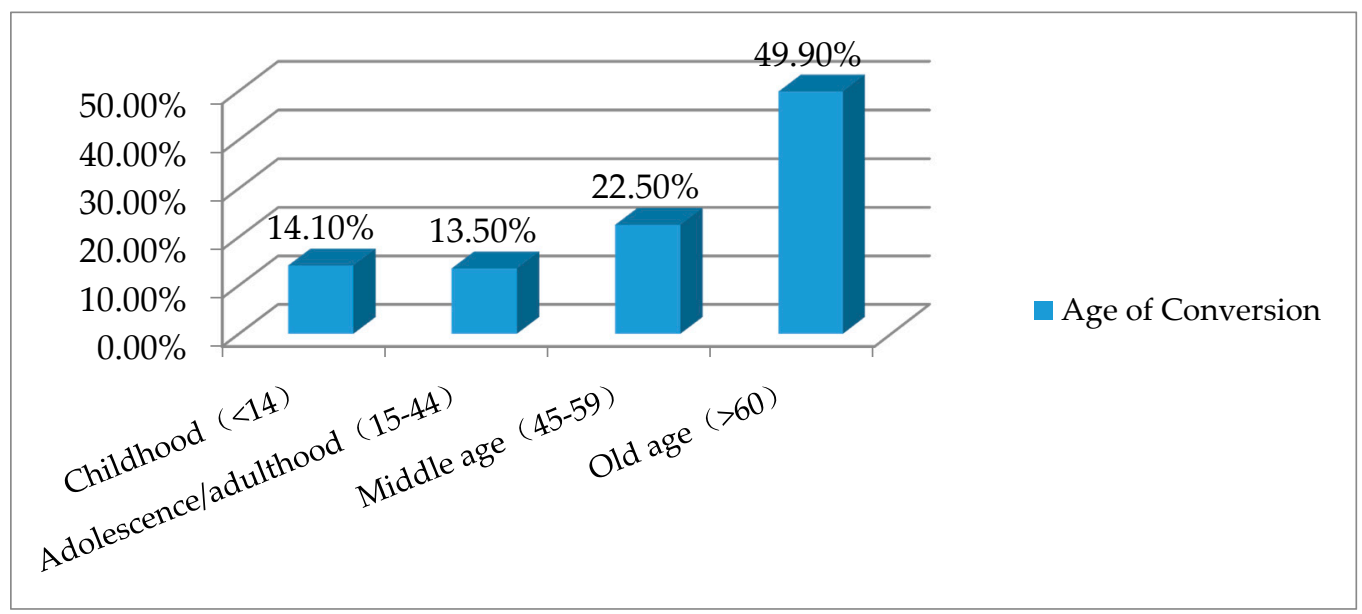

Figure 1. The age when city dwellers started their Christian faith.

\subsubsection{The Cause Why People Become a Member of Christianity}

Figure 2 addresses the cause why people become a member of Christianity. The highest influence is from family, $87.14 \%$. Additionally, one who is, or whose relatives are, diagnosed with a disease, or suffer from the death of family members are more committed to Christianity; $79.51 \%$ of the participants fall into this category. Other possible reasons are pressure relief, expanding social networks, and curiosity. Families and friends make a difference on the selection of faith, as does one's health condition.

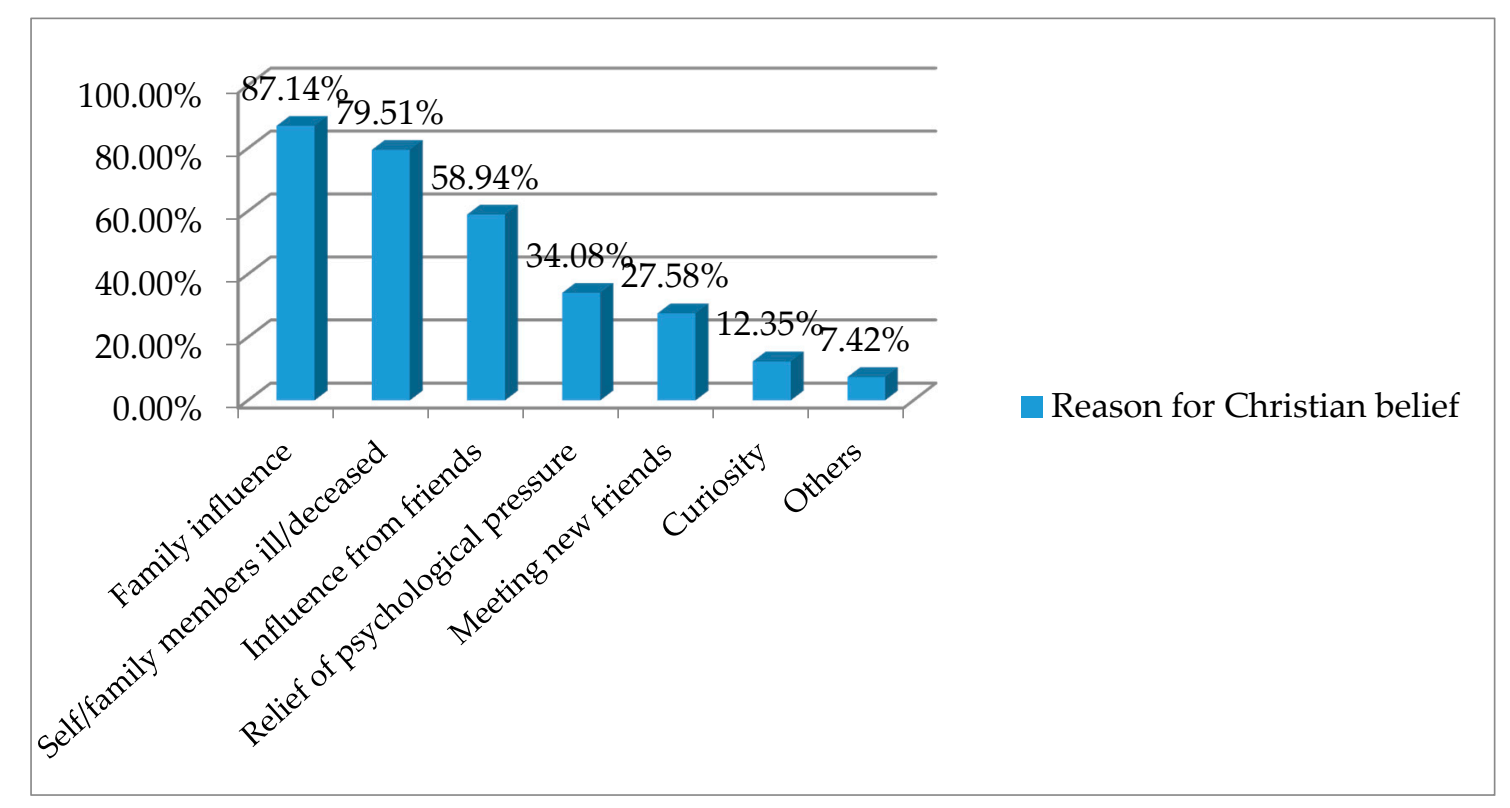

Figure 2. The cause why people become a member of Christianity. 


\subsubsection{How Enthusiastically City Dwellers Take Part in Christian Activities}

Figure 3 illustrates how often city dwellers take part in Christian activities. Overall, the participants do not show enthusiasm in these activities. Only $12.35 \%$ attend activities every week, while $22.49 \%$ confess that they never join in any of the organizations every month or every year.

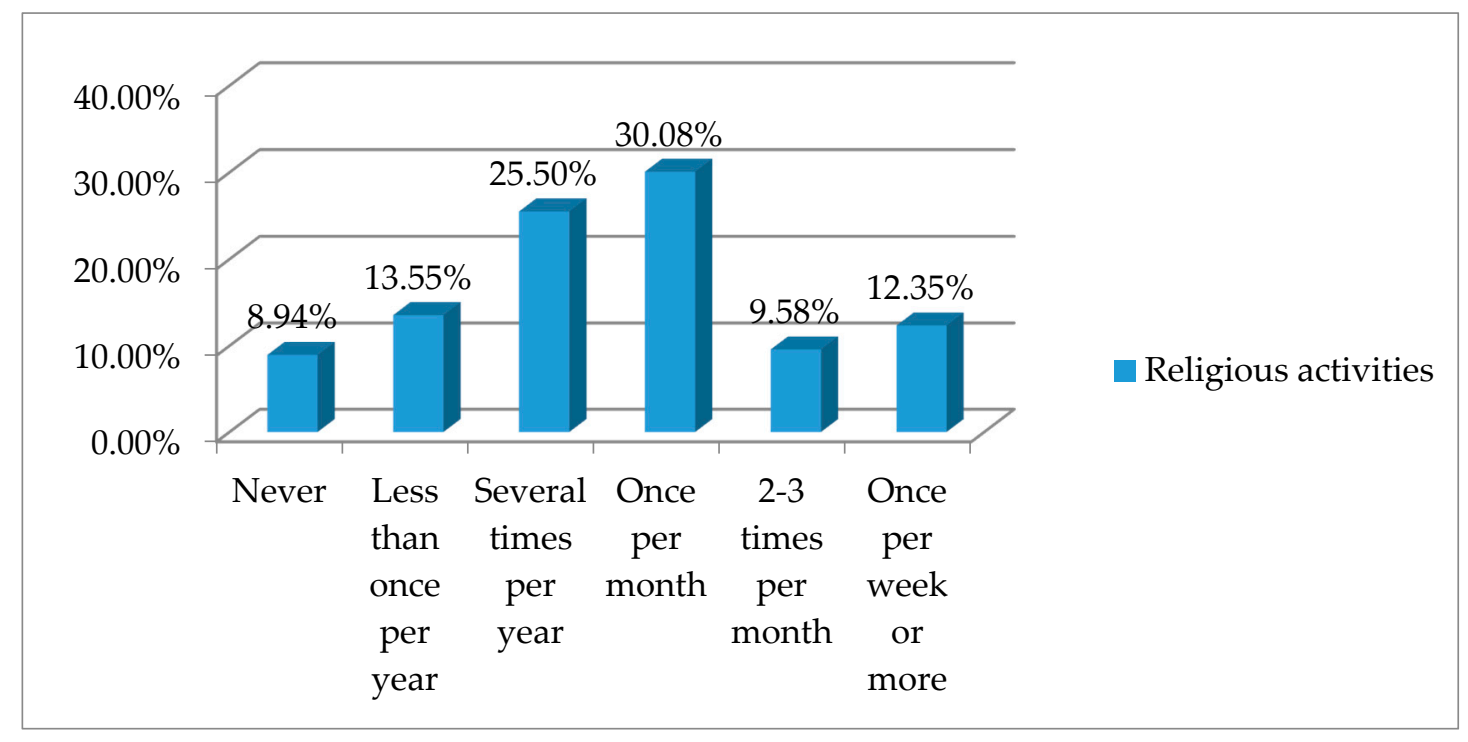

Figure 3. The frequency city dwellers participate in Christian activities.

\subsubsection{Where Are City Dwellers Take Part in Christian Activities}

Figure 4 shows the location of the city's religious activities. There are two main types of places where Christian believers carry out religious activities in mainland China. One is Christian churches registered at National College of Three-Self Patriotic Movement of the Protestant Churches in China (abbreviated as "National TSPM") and the Chinese Christian Council (abbreviated as "CCC"), referred to as the registered church. The other is a church that is not registered under the National TSPM and the CCC. They usually carry out religious activities in the form of family gatherings, with more locations are in the private house. The survey showed that $74.36 \%$ of the religious activities were carried out at registered locations and $18.8 \%$ of the religious activities were carried out at unregistered locations. Those who are not clear whether where their religious activities took place were registered take up $6.8 \%$.

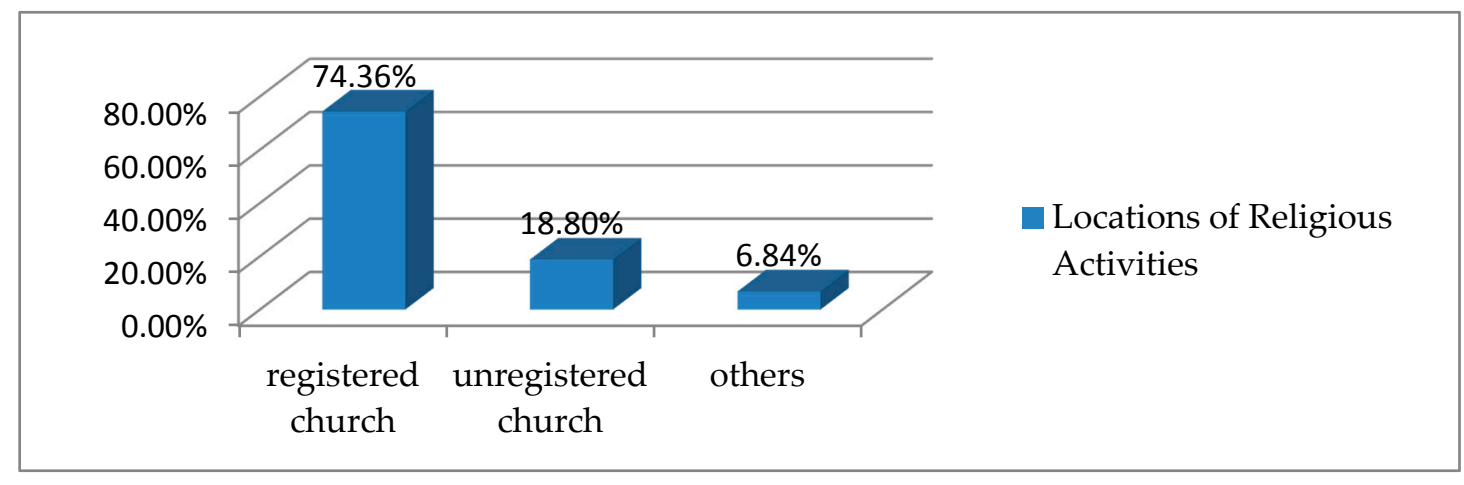

Figure 4. The locations city dwellers participate in Christian activities. 


\section{Empirical Analysis: Logistic Regression of Wuhan Residents' Belief in Christianity}

\subsection{The Description of Variables}

Dependent variable: whether the participant is Christian is the dependent variable. For this binomial variable, belief in Christianity denotes 1 , and non-belief denotes 0 .

Independent variable: demographic social economic indices of urban residents are chosen as the independent variables. This covers age, gender, marital status, nationality, political status, education, enterprise ownership, annual income, chronic disease, and social welfare. The detailed definitions are in Table 3.

Table 3. Definition of the main variables.

\begin{tabular}{|c|c|}
\hline Name of Variable & Description \\
\hline Christian belief & $\begin{array}{l}\text { Dummy variable; } 1 \text { for believing in Christianity, } 0 \text { for not believing in } \\
\text { Christianity. }\end{array}$ \\
\hline Gender & Dummy variable; 0 for women, 1 for men. \\
\hline Age & Continuous variable, the age of the participant. \\
\hline Marital status & $\begin{array}{l}\text { Construct three dummy variables: married, single, divorced or } \\
\text { widowed; } 1 \text { for when the participant's marital status matches the } \\
\text { description, and 0, otherwise. }\end{array}$ \\
\hline Ethnicity & Dummy variable; 0 for Han ethnicity, 1 for ethnic minorities \\
\hline Political affiliation & Dummy variable; 0 for unaffiliated, 1 for members of any party. \\
\hline Education & $\begin{array}{l}\text { Construct four dummy variables: primary school or below, middle } \\
\text { school, high school or high school level professional school, university } \\
\text { or above; } 1 \text { for when the education level of participant matches the } \\
\text { description, and } 0 \text {, otherwise. }\end{array}$ \\
\hline Employment category & $\begin{array}{l}\text { Construct } 5 \text { dummy variables: Party/government/government agency } \\
\text { or office/state-owned institution, state or collective owned enterprise, } \\
\text { individual-operated or private owned enterprise, foreign investment } \\
\text { enterprise, others. } 1 \text { for when the employment category of participant } \\
\text { matches the description, and } 0 \text { for otherwise. }\end{array}$ \\
\hline Annual income & Continuous variable, the annual income of participant. \\
\hline No. of chronic disease & $\begin{array}{l}\text { Continuous variable; } 0-5 \text { based on the actual condition of the } \\
\text { participant. }\end{array}$ \\
\hline Medical insurance & Dummy variable; 0 for having medical insurance, 1 , otherwise. \\
\hline Pension & Dummy variable; 0 for having pension, 1 , otherwise \\
\hline
\end{tabular}

\subsection{Research Method}

When measuring the factors in this study, we used a method which can best be described as logistic regression to include the binomial dependent variable (dichotomous variables).

The model is:

$$
\log \frac{p}{1-p}=\beta_{0}+\beta_{1} x_{1}+\beta_{2} x_{2}+\cdots+\beta_{k} x_{k}+u
$$

In this model, $\mathrm{p}$ stands for the possibility of an event. Here, it means the possibility that an urban resident is Christian. $\mathrm{x}_{1}, \mathrm{x}_{2}, \ldots, \mathrm{x}_{\mathrm{k}}$ are the factors that affects the urban residents to believe in Christianity. $\beta_{0}, \beta_{1}, \ldots, \beta_{\mathrm{k}}$ is the parameter that needs to be estimated. $u$ stands for stochastic disturbance team.

\subsection{Empirical Results and Analysis}

Table 4 presents data on the logistic regression study. Column 2 lists the coefficient, 3 lists the odds ratio, and 4 lists the marginal effect (dy/dx). 
Table 4. Logistic regression results of the determinants in urban residents' Christian beliefs.

\begin{tabular}{|c|c|c|c|c|}
\hline \multicolumn{2}{|r|}{ Variable } & \multirow{2}{*}{$\begin{array}{c}\text { Coef } \\
-0.154^{*} \\
(0.0900)\end{array}$} & \multirow{2}{*}{$\begin{array}{c}\text { Odds Ratio } \\
0.857^{*} \\
(0.501)\end{array}$} & \multirow{2}{*}{$\begin{array}{c}\mathbf{d y} / \mathbf{d x} \\
-0.0359 * \\
(0.0210)\end{array}$} \\
\hline & Gender & & & \\
\hline & Age & $\begin{array}{l}0.0691^{* *} \\
(0.0322)\end{array}$ & $\begin{array}{l}1.072 * * \\
(0.0346)\end{array}$ & $\begin{array}{l}0.00523 \text { ** } \\
(0.00244)\end{array}$ \\
\hline & Married & $\begin{array}{l}-0.492 * * \\
(0.248)\end{array}$ & $\begin{array}{l}0.612 * * \\
(0.152)\end{array}$ & $\begin{array}{l}-0.0671^{* *} \\
(0.0338)\end{array}$ \\
\hline & Single & $\begin{array}{l}-0.268 * \\
(0.159)\end{array}$ & $\begin{array}{l}0.765^{*} \\
(0.122)\end{array}$ & $\begin{array}{l}-0.0366^{*} \\
(0.0218)\end{array}$ \\
\hline & Ethnicity & $\begin{array}{l}0.154 \\
(0.202)\end{array}$ & $\begin{array}{l}1.167 \\
(0.236)\end{array}$ & $\begin{array}{c}0.0358 \\
(0.0469)\end{array}$ \\
\hline & Affiliation with CCP or other political parties & $\begin{array}{l}-2.080 * * * \\
(0.501)\end{array}$ & $\begin{array}{l}0.125^{* * * *} \\
(0.0626)\end{array}$ & $\begin{array}{l}-0.484^{* * *} \\
(0.115)\end{array}$ \\
\hline \multirow{3}{*}{ Education } & Middle school & $\begin{array}{c}0.157 \\
(0.262)\end{array}$ & $\begin{array}{c}1.169 \\
(0.306)\end{array}$ & $\begin{array}{c}0.0364 \\
(0.0608)\end{array}$ \\
\hline & High school or high school level professional school & $\begin{array}{l}-1.278^{* *} \\
(0.509)\end{array}$ & $\begin{array}{c}0.279 * * \\
(0.142)\end{array}$ & $\begin{array}{l}-0.297^{* *} \\
(0.118)\end{array}$ \\
\hline & University or above & $\begin{array}{l}-1.652 * * * \\
(0.559)\end{array}$ & $\begin{array}{l}0.192 * * * \\
(0.107)\end{array}$ & $\begin{array}{l}-0.384^{* * *} \\
(0.129)\end{array}$ \\
\hline \multirow{8}{*}{$\begin{array}{l}\text { Employment } \\
\text { category }\end{array}$} & $\begin{array}{l}\text { Party/government/government agency or } \\
\text { office/state-owned institution }\end{array}$ & $\begin{array}{l}-1.568^{* * *} \\
(0.478)\end{array}$ & $\begin{array}{l}0.208^{* * *} \\
(0.0997)\end{array}$ & $\begin{array}{c}-0.119^{* * *} \\
(0.0362)\end{array}$ \\
\hline & State or collective owned enterprise & $\begin{array}{c}-0.0259 \\
(0.273)\end{array}$ & $\begin{array}{c}0.974 \\
(0.266)\end{array}$ & $\begin{array}{l}-0.00354 \\
(0.0372)\end{array}$ \\
\hline & Individual-operated or private owned enterprise & $\begin{array}{c}0.202 \\
(0.127) \\
\end{array}$ & $\begin{array}{c}1.224 \\
(0.156)\end{array}$ & $\begin{array}{c}0.0275 \\
(0.0174)\end{array}$ \\
\hline & Foreign investment enterprise & $\begin{array}{l}-0.0213 \\
(0.0284)\end{array}$ & $\begin{array}{c}0.979 \\
(0.0278)\end{array}$ & $\begin{array}{c}-0.00290 \\
(0.00387)\end{array}$ \\
\hline & Annual income & $\begin{array}{c}-2.589^{* * * *} \\
(0.469)\end{array}$ & $\begin{array}{c}0.0751^{* * * *} \\
(0.0352)\end{array}$ & $\begin{array}{c}-0.196^{* * *} \\
(0.0355)\end{array}$ \\
\hline & No. of chronic diseases & $\begin{array}{c}2.254^{* * *} \\
(0.354)\end{array}$ & $\begin{array}{c}9.529^{* * * *} \\
(3.374)\end{array}$ & $\begin{array}{l}0.171^{* * *} \\
(0.0272)\end{array}$ \\
\hline & Medical insurance & $\begin{array}{c}1.013^{* * * *} \\
(0.319)\end{array}$ & $\begin{array}{c}2.752^{* * *} \\
(0.877)\end{array}$ & $\begin{array}{c}0.0767^{* * *} \\
(0.0243)\end{array}$ \\
\hline & Pension & $\begin{array}{c}0.113 \\
(0.221)\end{array}$ & $\begin{array}{c}1.119 \\
(0.248)\end{array}$ & $\begin{array}{l}0.00854 \\
(0.0168)\end{array}$ \\
\hline
\end{tabular}

Log likelihood $=-487.85315, \mathrm{LR}_{\mathrm{chi}^{2}}=312.48$, Pseudo- $\mathrm{R}^{2}=0.2426$

Notes: 1 . The reference variables for marital status, education degree, occupation, are the divorced or widowed, elementary school and below, or other. 2 . The number in the bracket is the standard error, ${ }^{*}, * *, * * *$, represent the significance under the levels of $10 \%, 5 \%$, and $1 \%$.

As Table 4 shows, under the same conditions, age has a significant effect on urban residents' belief in Christianity: the greater the age, the more possible the respondent is to be Christian. In terms of gender, female urban residents are more likely to be Christian believers compared with male residents. In terms of marital status, compared with married or single urban residents, divorced or widowed urban residents are more likely to belief in Christianity.

For education level, the regression analysis, with "primary school or less" as reference variable, informs that compared with urban residents who have primary school education or less, those who have completed middle school do not have significant difference in possibility of being Christian, but the urban residents with high school, university or higher education are less likely to believe in Christianity. As for income level, the regression analysis result shows that the higher the income, the more unlikely one is to believe in Christianity, the lower the income, the more likely. Some possible reasons might be: Firstly, living pressure. As is around the world, in China, lower educational level often corresponds to lower income, lower social status, and heavier psychological pressure about living. Therefore, one of the most important reasons to believe in Christianity is to relieve living pressure. Secondly, lack of diverse ways to acquire psychological comfort. Well-educated urban residents may use diverse ways to manage psychological pressure, such as travelling and 
reading. Less educated urban residents, on the other hand, due to financial constraint, have fewer channels to relieve psychological pressure, and therefore are more likely to join Christianity to acquire spiritual comfort.

For political affiliation, compared with those of no political affiliation, those who are members of Chinese Communist Party or Democratic Parties are less likely to believe in Christianity. A possible explanation could be that in China, if one wants wo join the Communist Party, he or she is not allowed to believe in any religion but Communism. Therefore, the CCP members who secretly converted to Christianity or other religions rarely openly declare their faith. China's Democratic parties consists of 8 parties: KMT Revolutionary Committee, Democratic League, Democratic National Construction Association, Association for Promoting Democracy, Peasants' and Workers' Democratic Party, Party for Public Interest, Jiusan Society, and Taiwan Democratic Self-Government League. The members of these parties are mainly intellectuals and prestigious people of different occupations. They are usually well-educated, socially prestigious, with high income and abundant social activities. They have their own party beliefs and are less likely to be believers of Christianity in China. Even though they have been converted, they are often reluctant to disclose their Christian identity.

In terms of occupational categories, those who work in CCP, government, government agency or office or state-owned institutions are less likely to believe in Christianity. It might be explained by the desirability of a job in the Party or government, due to its stability, secure and relatively high income, good working environment and high social status. Therefore, the competition for such jobs is high, and only outstanding college graduates are possible to win such a job. Meanwhile, many of those governmental institutions require the applicant to be a CCP member, which increased the proportion of CCP members. The special and admired social status makes it less likely for urban residents who work in these institutions to be Christian.

As for health conditions, with the increase of chronic diseases, the possibility of urban residents' belief in Christianity also increases. This reaffirms the result of the Figure 3, that having disease is one of the most important reason for urban residents to believe in Christianity. The analysis also discovers that the urban residents without medical insurance are more likely to be Christian than those with medical insurance. It could possibly be explained that China does not have free medical care system. Therefore, medical treatment is often an unbearable financial burden for citizens. Participation in the health insurance system can reduce the economic burden of the patient to a certain extent. But for those who do not participate in the medical insurance system, when they are sick, they may not be able to afford expensive medical expenses and choose not to go to the hospital, but appeal to their faith instead to pray for their own illness to be healed.

\section{Conclusions}

Through the empirical analysis during the survey, in this chapter we will summarize and analyze the status of Chinese urban Christians.

\subsection{Notable Group Characteristics: High Proportion of the Elderly, Women and Less Educated People}

First of all, females take up a greater proportion in urban Christians. In our survey, the proportion of women in the Christian community was as high as $58.12 \%$ and the male was $41.88 \%$. In contrast, the proportion of women was $51.36 \%$ in the group without any religion, the proportion of males was $48.64 \%$. We found that, first, women are more likely to be influenced by family and friends and believe in Christianity. Considering the research samples (see Figure 3), the main reasons for urban residents to believe in Christianity are influence from religious family members, and the illness of their family members and their own. We intend to provide an explanation for the higher proportion of female Christians through the analysis of relationships between gender and religious family members, and between gender and chronic diseases. In the analysis, we divided the samples into male samples and female samples, and made a variable for these two groups of "before you believe in Christianity, whether your family or friends believe in Christianity" with the variable "whether they believe in 
Christianity". Correlation analysis showed that the correlation coefficient of female samples was 0.89 , while the correlation coefficient of male samples was 0.77 . It indicates that women are more susceptible to family and friends' influence. Second, when suffering from disease, compared with men, women are more inclined to pray to God to ease the pain. When we analyzed at least one group of chronic diseases, we found that the proportion of male's belief of Christianity was 3.03\%, compared with $3.41 \%$ for women: more women than men. In the discussion with the participants we also found that especially when chronic diseases cannot be completely cured, women are more likely to turn to faith to reduce the pain. This is also the case when the family or himself is suffering from a major disease that cannot be cured. Six women among all interviewees suffer from chronic disease, and four of them claimed that they converted to Christianity after being diagnosed with diseases such as diabetes and arthritis, in the hope that their pain could be eased.

Secondly, the proportion of elderly urban residents who believe in Christianity is higher. In our study, in the Christian group, the age of 60 and older accounted for $48.72 \%$, while in the group of no religion, the elderly aged 60 and older accounted for only $26.97 \%$. We found that: on the one hand, the proportion of older people with chronic disease is higher than that of young people, and to eliminate the pain through the faith of Christ is one of the important reasons Chinese urban residents believe in Christianity. On the other hand, in China, with the acceleration of the geographical population mobility, many children of the elderly, because of the study, work, marriage and other reasons, move to different places and even settle in foreign countries, resulting in urban "empty nest" elderly people. Many elderly people join Christianity in order to dispel loneliness, so that they can go to church for worship and attend church activities. Figure 3 also shows that making friends is also one of the reasons why Chinese urban residents believe in Christianity, accounting for $27.58 \%$.

Finally, the Christian urban residents are less educated. Among the groups surveyed, $62.39 \%$ of the population of Christianity have the education level of middle school and below, while the proportion of middle school and below educational level was $47.05 \%, 15.34 \%$ less, in groups that did not believe in any religion. We find that lower education level is associated with lower income and poor health condition, while lower incomes and poor health levels contribute to urban residents' conversion to Christianity. Then, in the interview following the survey, we found that the lower level of education groups tends to think their social status low and have greater psychological pressure. To ease the psychological pressure through the Christian faith is also one of the main reasons the city residents believe in Christianity. At the same time, when they encounter difficulties in life, the church and the believers can also provide support to help them solve practical problems, which also leads them to believe in Christianity. 39 of all 44 interviewees reported of receiving some form of assistance from the church or other fellow Christians.

\subsection{Some Believers Have Little Knowledge of Christian Doctrines and Have Different Degrees of Practicality and Utilitarianism in Their Purpose of Joining Christianity}

As shown in Figure 2, the number of surveyed Christians who participate in religious activities less than once each month reaches the proportion of $22.49 \%$, close to quarter of the sample. It indicates that the proportion of Christian believers who participate frequently in religious activities is not high. Meanwhile, in the investigation process found that a considerable proportion of Christians do not really care about Christian doctrines, nor do they know much about the rules and constraints that Christians should follow. Many Christians choose to believe in Christianity in order to solve the problems that arise in real life. They do not care whether Jesus can bring them happiness in the kingdom come and the fear of the hell. Many chose to believe Christianity as a result of family poverty, hoping for a miracle; some women believe because of marital crisis or family conflicts, hope that through their own faith in Christianity they can change the status quo. Christian preachers, when they preach to them, often persuade them by examples of healing the incurable diseases by believing in Jesus in China. 
Because the Christian converts do not believe in doctrines, it turns out that the entry and exit of the Christianity are at the discretion of Chinese urban Christians. In China, to be received into a Christian order or congregation is very simple, even less costly than Buddhism which requires expensive rituals, and the missionaries often promise they can exit anytime if they did not feel the care from God. A lot of people joined Christianity to have a try. The Christian associations are laxly regulated, so the Christians are allowed to cancel the religious activities, or exit, without any concerns. Some Protestants withdraw from the Christianity because of many reasons, such as too much work, cannot make it to various religious activities and so on, and then join again, and it can occur repeatedly.

\subsection{Home Church as a Common Form of Religious Practice}

According to the incomplete statistics of the Wuhan municipal government, of all Christian believers, the proportion of Christians attending religious activities in non-registered places increased from $7 \%$ to almost $11 \%$ in the period from 2010 to 2013. Meanwhile, of all newly converted Christian believers, the proportion of people converted at non-registered locations increased from $18 \%$ in 2010 to 33\% in 2013. It can be seen that "home church" exhibits the rapidest growth in organizing religious activities. As shown in Figure 4, our survey data in 2015 showed that nearly 19\% of respondents made it clear that they were recently engaged in religious activities at the "home church" at non-registration points.

In China, the National TSPM and the CCC registered churches need to accept the government's management. As a result, the believers must carry out religious activities in government-designated places and the priest is subject to government approval. Much of the religious administration and personnel arrangements, sometimes even the church's own property management, are subject to government administration. This strict control of the government has led many churches to be reluctant to accept governmental management, and many Christians have turned to relatively free home churches and have contributed to its rapid development. At the same time, we found that some of the believers turned to home churches because of the lack of registered locations and unreasonable geographical layouts that could not meet the daily needs of Christians for religious activities. For example, according to the Wuhan municipal government statistics show that in 2013, Wuhan has the resident population of 10,607,700 people. According to our survey of the proportion of Christian believers as $2.86 \%$, in projection, about 30.34 million Christian believers live in Wuhan city. As the data shows in October 2013 in Wuhan City, Christian registered religious locations count 116, and most of them are situated in the old city, where the traffic is not convenient, far from meeting the needs of believers for religious activities.

In the course of the investigation, we also found notable evidence of a new form of home church in urban China. Vastly different from the traditional home church, this kind of city new home church openly declares its faith, believers confess openly of their faith, and believers mostly consist of young urban people, such as college students, master students. The majority of the new home churched did not establish an independent church, but rent or purchase office buildings for religious activities, emphasizing the democratization of organizational management. At the same time, the city's emerging "home churches", although not accepted as a registered location for religion, have paid attention to building relationship with government, taking the initiative to dialogue with the government, and often are registered as social organization under relevant governmental agencies. In our study, in Wuchang District, Wuhan City, there is home church organized by school teachers, which in five years has expanded to three divisions. Many of the believers who come here to participate in religious activities are young people, some of whom have studied abroad, and have attracted many foreigners living in Wuhan. There are regular religious activities with rich content. It often holds badminton and table tennis competition, has excellent service facilities, and there is also a personal care of children's entertainment room to cater to those parents with children. This new "house church" provides a more diversified approach and favorable conditions for the spread of Christianity in China's urban areas, developing rapidly and attracting social attention. 
4.4. Christianity Had an Impact on the Life of Believers, but Did Not Challenge the Deep-Rooted Customs and Traditions in Urban Life

The survey found that Christianity had a great impact on the life of Chinese urban believers. Firstly, Christianity played a role in psychological comfort. $34.08 \%$ of the respondents choose to believe in Christianity to ease the psychological pressure. Through discussion with some of the interviewed respondents, we found that Christianity, they claimed, brought them peace of mind, tolerance for people and issues around them, and courage to face difficulties in life. Psychological balance, to a certain extent, reduces the possibility of conflict at all levels of society, and promote the stability of China's urban society. Secondly, Christianity played a positive role in moral education. Christianity, based on equality and fraternity, advocates kindness, help and understanding for each other to live in harmony. Christianity influences believers with their teachings and values and thus influences the believer's social circle. Some of the respondents found themselves and the surrounding people not only trying to avoid doing bad things, but also help others as much as possible. Thirdly, Christianity is an "emotional bond" between people. With the rapid transformation of contemporary Chinese society, the relationship between people in modern society is increasingly aloof, with little emotional communication. Christianity, to a certain extent, facilitated the association between people. The brotherhood and sisterhood between believers in a way make up for the absence of intimate interpersonal relationships in modern life, meeting people's spiritual life in the emotional and psychological needs.

However, despite the significant influence of Christianity on its believers, it does not override the influence of traditional ethics. According to the survey, apart from attending the activities of church regularly or intermittently, the Christian still live in a tradition lifestyle. In terms of traditional Chinese celebrations or of social networking, most of them live by the traditional customs. Even though the believers regard fellow Christians as brothers and sisters, after they return to every life, they abide by traditional ethics in front of relatives and friends. For example, in funerals, they still kneel and mourn according to the traditional Chinese custom. For them, there is no conflict in believing Christian and kneeling in front of the deceased; all these rites demonstrate the respect and care to the bereaved.

Although our research has given some interesting findings, we are not able to claim their validity on a national basis. Our research site, Wuhan, is a typical city of central China, but it could not represent the various urban development, economic development and cultural customs across eastern, central and western China. Therefore, researchers who wish to explore whether our findings can be applied to other regions of China should select cities in eastern or western regions and conduct further surveys, in order to obtain more diversified samples. We look forward to studies that fully reflect Chinese Christians' urban life and the basic characteristics.

Acknowledgments: This research was supported by the National Social Science Foundation (project 15CGL046 and16CGL046), the Youth Foundation of Humanities and Social Sciences by Ministry of Education of the People's Republic of China (project 15YJCZH118), the Scientific Research Projects by the State Ethnic Affairs Commission (projects 14ZNZ005and MSQ16002), and the Fundamental Research Funds for the Central Universities (projects CSY16018 and 410500076).

Author Contributions: The authors are jointly responsible for the entire article, though the literary and the survey sections primarily written by Yingying Meng, and the empirical analysis and conclusion sections primarily written by Junqiang Han. Chengcheng Xu and Siqi Qin responsible for collecting and cleansing the data.

Conflicts of Interest: The authors declare no conflict of interest.

\section{References}

Aikman, David. 2003. China's Christian Future? Arlington: American Spectator.

Cao, Nanlai. 2013. Renegotiating Locality and Morality in a Chinese Religious Diaspora: Wenzhou Christian Merchants in Paris, France. Asia Pacific Journal of Anthropology 14: 85-101. [CrossRef]

Chen, Cun Fu, and Yu Bo Wu. 2005. Contemporary Rural Christianity in Urbanization (城市化过程中的当代农村 基督教). World Religious Cultures 2: 65-70. 
Hackett, Conrad, Brian J. Grim, Vegard Skirbekk, Marcin Stonawski, and Anne Goujon. 2011. Global Christianity: A Report on the Size and Distribution of the World's Christian Population. Washington: Pew Research Center.

Jay, Jennifer W. 1997. Christianity in China: From the Eighteenth Century to the Present. History Reviews of New Books 25: 182. [CrossRef]

Kang, Jie. 2015. The Concept of Social Network in Chinese Christianity (中国基督教的社会网络概念). Cultural Diversity in China 1: 219-32. [CrossRef]

Landryderon, Isabelle, and Rolf Gerhard Tiedemann, eds. 2011. Handbook of Christianity in China. Volume Two: 1800 to the Present. Paris: Éditions de l'EHESS, pp. 281-82.

Li, Feng. 2015. New Generation's Attitude towards Christianity and Mediating Mechanisms: Data Based on Yangtze River Delta (新生代对基督教的信任态度及中介机制以长三角地区数据为例). Society 35: 137-65.

Lu, Xian Min, and Pu Fang Chen. 2006. The Construction of Spiritual Civilization in the Countryside From the Spread of Christianity (从基督教的传播看现阶段农村的精神文明建设). Agricultural in Gansu 2: 27-28.

Lu, Yun Feng, and Chun Ni Zhang. 2016. An observation of Christianity in contemporary China: Based on the data of CGSS and CFPS (当代中国基督教现状管窥: 基于CGSS和CFPS调查数据). World Religious Cultures 1: 34-46.

Mooney, Paul. 2004. An Amazing Tale of Christianity in China. Kansas City: National Catholic Reporter.

Nie, Zi Lu. 2000. Historical analysis of a century's American Christian missionary in China (百余年来美国的基督 教在华传教史研究). Modern History Studies 1: 255-96.

People's Republic of China. 2015. China Statistics Yearbook 2015 (中国统计年鉴2015). Beijing: China Statistics Press.

Pye, Lucian Wilmot. 2005. Jesus in Beijing: How Christianity is Transforming China and Changing the Global Balance of Power by David Aikman. Foreign Affairs 83: 158. [CrossRef]

Religion and Culture Research Task Group of PKU, and Yun Feng Lu. 2014. Report on religion in contemporary China: based on CFPS (2012) data (当代中国宗教状况报告一基于CFPS (2012) 调查数据). World Religious Cultures 1: 11-25.

Ruan, Rong Ping, and Li Liu. 2011. A Study of Informal Social Security Provision in Rural China: Analysis Based on the Social Security Function of Religion (中国农村非正式社会保障供给研究一基于宗教社会保障功能的分 析). Management World Journal 4: 46-57.

Ruan, Rong Ping, Feng Tian Zheng, and Li Liu. 2014. The power of belief: Does religion benefit entrepreneurship (信仰的力量: 宗教有利于创业吗)? Economic Research 3: 171-84.

Standaert, Nicolas, and Rolf Gerhard Tiedemann, eds. 2001. Handbook of Christianity in China. Leiden: Brill.

Tsai, Lily L. 2007. Solidary Groups, Informal Accountability, and Local Public Goods Provision in Rural China. American Political Science Review 101: 355-72. [CrossRef]

Wang, Zuo An. 2014. Speech commemorating 60 years of establishment of National Committee of Three-Self Patriotic Movement of the Protestant Churches and the opening ceremony of Nationalizing Christianity Seminar (纪念中国基督教三自爱国运动委员会成立60周年暨基督教中国化研讨会开幕式上的讲话). Tianfeng 9: 4-6.

Xing, Fu Zeng. 2007. Regional development of Chinese Religions: 1918, 1949, 2004. Christianity Academic Review in Mandarin 3: 153-97.

Yang, Fenggang. 2006. The Red, Black, and Gray Markets of Religion in China. The Sociological Quarterly 47: 93-122. [CrossRef]

Yang, Fenggang. 2010a. Lost in the Market, Saved at McDonald's: Conversion to Christianity in Urban China. Journal for the Scientific Study of Religion 44: 423-41. [CrossRef]

Yang, Fenggang. 2010b. Chinese Christians in America: Conversion, Assimilation, and Adhesive Identities. Philadelphia: Penn State Press.

Yao, Mi Jia, Jian Hua Wang, and Hong Quan Liu. 2003. Analysis of the reason for rapid expansion of Chrisitianity in Xi'an since 1979 (改革开放以来西安地区基督教传播速度加快原因分析). Xi'an Liberal Arts College Academic Journal (Social Sciences) 6: 62-66.

Zheng, Feng Tian, Ruan Ping Ruan, and Li Liu. 2010. Risk, social security and rural religious belief (风险、社会保 障与农村宗教信仰). Economics Quarterly 9: 829-50.

(C) 2017 by the authors. Licensee MDPI, Basel, Switzerland. This article is an open access article distributed under the terms and conditions of the Creative Commons Attribution (CC BY) license (http://creativecommons.org/licenses/by/4.0/). 